\title{
Study of post cesarean section wound infection and microbiological epidemiology in tertiary care centre, Western Rajasthan, India
}

\author{
Nehal Sahay*, Rekha Jhakhar
}

Department of Obstetrics and Gynecology, Dr. S. N. Medical College, Jodhpur, Rajasthan, India

Received: 26 February 2020

Accepted: 30 March 2020

\section{*Correspondence:}

Dr. Nehal Sahay,

E-mail: nehalsahay@gmail.com

Copyright: (C) the author(s), publisher and licensee Medip Academy. This is an open-access article distributed under the terms of the Creative Commons Attribution Non-Commercial License, which permits unrestricted non-commercial use, distribution, and reproduction in any medium, provided the original work is properly cited.

\begin{abstract}
Background: Surgical site infection (SSI) following C-section is a common encountered problem and needs to be analysed. In this study we have determined the incidence, risk factors and common bacterial pathogens in surgical site infection (SSI) following C-section at a tertiary care centre.

Methods: A hospital based prospective study conducted for a period of 6 months. Those women whose C-section was complicated by SSI within 5 days postoperatively were included in the study. Risk factors for SSI were identified and microbiological pattern was studied.

Results: Out of 62 women whose C-section was complicated by SSI within 5 days post-operatively, during this study period post cesarean SSI incidence was $0.34 \%$. In this study post C-section SSI found as high as $43.55 \%$, in lower socio-economic status. Among all patients, un-booked were $62.90 \%$, Referred patients were as high as $67.74 \%$. SSI developed in $69.35 \%$ patients without preoperative antibiotic prophylaxis. C-section done in PROM in $64.50 \%$ and as an elective emergency $79.03 \%$, blood transfusion needed in $59.68 \%$ and type of incision being transverse (Pfannenstiel) in $88.71 \%$. Subcutaneous suture technique used in $75.81 \%$ and secondary healing occurred in $67.74 \%$. Most common organism grown was CoNS (coagulase negative staphylococcus) $29.03 \%$ in SSI.

Conclusions: To reduce SSI, the hospital infection control system and surgical site infection surveillance program has to be established. Knowing the prevalence and risk factors will help optimal precaution and standard surgical technique to reduce SSI, which causes increased hospital stay of patients.
\end{abstract}

Keywords: Micro-organism, Post lower segment cesarean section, Surgical site infection

\section{INTRODUCTION}

Caesarean delivery is a major obstetrical surgical procedure aiming to save the lives of mothers and foetuses. The incidence of $\mathrm{C}$-section deliveries both primary and repeat has risen dramatically over the last few decades, with an estimated global number of 22.9 million C-section deliveries in 2012. ${ }^{1}$ More than a century earlier, the concepts of antisepsis and infection prevention in surgical practices were realized, this was later boosted by the use of preoperative antibiotics at correct dose and time. Any breach in the integrity of skin and mucous membranes is a risk factor to acquisition of infection by either endogenous or exogenous organisms. ${ }^{2}$ Surgery itself is a risk factor for acquisition of infection, including nosocomial infection. Malnutrition and low socio-economic status further exacerbate the risk of infection. C-section carries 20-fold increase risk of infection compared to normal vaginal delivery. ${ }^{2}$ The knowledge of risk factors associated with surgical site infection is essential to develop targeted prevention strategies and reduce the risk of infection.

Surgical site infection affects the superficial tissues, but some serious infections affect the deeper tissues or other parts of the body manipulated during the procedure. 
Majority of surgical site infections become apparent within 30 days of an operative procedure and most often between $5^{\text {th }}$ and $10^{\text {th }}$ post-operative day. ${ }^{3}$ Further it caused to increase stay of hospital and cost of treatment. SSI can be frustrating for the mother trying to recover from the procedure and at the same time take care of the new-born. Knowing the prevalence and associated risk factors would help to take optimal precautions and standard surgical techniques to reduce surgical site infection which poses increased hospital stay of the patients.

Objective of this study was to estimate the incidence, study bacteriology, and the factors associated with the occurrence of SSI in the study setting.

\section{METHODS}

This was a prospective observational study done at department of obstetrics and gynaecology, Umaid Hospital, Dr. S. N, Medical College, Jodhpur, Rajasthan from June 2018 to November 2018 to determine the incidence of surgical site infection post cesarean within 5 days of post-operative period.

\section{Inclusion criteria}

- The data was collected from patients who developed surgical site infection following $\mathrm{C}$-section within 5 days of post-operative period.

\section{Exclusion criteria}

- Those patients who were not willing to participate in the study were excluded from the study. Patients who were already receiving antibiotics for $>1$ week, patients undergoing re-operations.

A pre-designed questionnaire will be used in the study. This will be a hospital-based study. Details of patients like Age, BMI, socio-economic status, antenatal booking, referral status, parity, previous medical history and abdominal surgery history, preoperative haemoglobin status, prophylactic antibiotic and corticosteroid status, surgical site preparation method, C-section done during which stage of labor and, with or without intact membranes, as an elective or as an emergency surgery, need for blood transfusions, intra-operative factors like length and type of incision, duration of surgery, uterine exteriorisation, type of closure and healing of wound infection either spontaneous secondary healing or resuturing done, most common micro-organism grown, most common sensitive drug and most common drug resistance were studied using a preformed questionnaire after informed consent.

SSI was diagnosed as per the guidance issued by the centre for disease prevention and control (CDC, Atlanta1991). An "operation" was defined as any procedure involving skin incision, undertaken in an operation theatre under anaesthesia.

\section{Statistical analysis}

The data were processed in the statistical package for social sciences software for windows, version 12 . The association was tested using the test of statistical significance for the difference between the two proportions- the Chi-square test and for the difference between the two means - the student's t-test, at 5\% level of significance.

\section{RESULTS}

The percentage comparison of patient's age, weight, height, socio-economic status, booking status, referral status and pre-operative history that developed SSI is as tabulated in Table 1.

Table 1: Age, weight, height, socio-economic status, booking status, referral status and pre-operative history of patients with SSI.

\begin{tabular}{|c|c|c|c|}
\hline Variable & & Frequency (n) & $\%$ \\
\hline \multirow{3}{*}{ Age } & $<24$ & 16 & $25.80 \%$ \\
\hline & $25-29$ & 20 & $32.26 \%$ \\
\hline & $>30$ & 26 & $41.94 \%$ \\
\hline \multirow{4}{*}{ Weight } & $<55$ & 3 & $4.84 \%$ \\
\hline & $56-70$ & 22 & $35.48 \%$ \\
\hline & $71-80$ & 12 & $19.35 \%$ \\
\hline & $81-90$ & 25 & $40.32 \%$ \\
\hline \multirow{3}{*}{ Height } & $<149$ & 10 & $16.13 \%$ \\
\hline & $150-160$ & 37 & $59.68 \%$ \\
\hline & 161 & 15 & $24.19 \%$ \\
\hline \multirow{3}{*}{$\begin{array}{l}\text { Socio- } \\
\text { economic } \\
\text { status }\end{array}$} & Higher & 12 & $19.35 \%$ \\
\hline & Middle & 23 & $38.10 \%$ \\
\hline & Lower & 27 & $43.55 \%$ \\
\hline Booked & & 23 & $38.10 \%$ \\
\hline Unbooked & & 39 & $62.90 \%$ \\
\hline \multirow{2}{*}{ Referred } & Yes & 42 & $67.74 \%$ \\
\hline & No & 20 & $32.26 \%$ \\
\hline Primi & & 31 & $50 \%$ \\
\hline Multi & & 31 & $50 \%$ \\
\hline \multirow{4}{*}{$\begin{array}{l}\text { Pre-existing } \\
\text { medical } \\
\text { disorders }\end{array}$} & URI & 5 & $8.06 \%$ \\
\hline & PIH & 14 & $22.58 \%$ \\
\hline & GDM & 10 & $16.13 \%$ \\
\hline & NIL & 33 & $53.23 \%$ \\
\hline \multirow{2}{*}{$\begin{array}{l}\text { Surgical } \\
\text { history }\end{array}$} & Yes & 32 & $51.61 \%$ \\
\hline & No & 30 & $48.39 \%$ \\
\hline
\end{tabular}

Table 2 shows the pre-operative investigation and history (haemoglobin, antibiotic status, corticosteroid, hair removal, C-section done at $\left(1^{\text {st }}\right.$ stage $/ 2^{\text {nd }}$ stage $)$, membrane intact/absent, elective/emergency, blood transfusion) of the patients who developed SSI. 
Further, variable organisms grown report, drug sensitivity report and drug resistance report among antibiotics of the patients who have developed SSI is as shown in Table 3, Table 4 and Table 5 respectively.

Table 2: Pre-operative investigation and history report of patients with SSI.

\begin{tabular}{|c|c|c|c|}
\hline & & Frequency (n) & $\%$ \\
\hline \multirow{5}{*}{$\begin{array}{l}\text { Pre-op } \\
\text { haemoglobin }\end{array}$} & $<5$ & 3 & $4.84 \%$ \\
\hline & $5-7$ & 15 & $24.19 \%$ \\
\hline & $7.1-8$ & 11 & $17.74 \%$ \\
\hline & $8-10$ & 16 & $25.81 \%$ \\
\hline & $>10$ & 17 & $27.42 \%$ \\
\hline \multirow{2}{*}{$\begin{array}{l}\text { Pre-op } \\
\text { antibiotic status }\end{array}$} & Yes & 19 & $30.65 \%$ \\
\hline & No & 43 & $69.35 \%$ \\
\hline \multirow{2}{*}{$\begin{array}{l}\text { Preop } \\
\text { corticosteroid }\end{array}$} & Yes & 27 & $43.55 \%$ \\
\hline & No & 35 & $56.45 \%$ \\
\hline \multirow{2}{*}{$\begin{array}{l}\text { Pre-op hair } \\
\text { removal }\end{array}$} & $\begin{array}{l}\text { Razor } \\
\text { removal }\end{array}$ & 41 & $66.13 \%$ \\
\hline & Not done & 21 & $33.87 \%$ \\
\hline \multirow{2}{*}{$\begin{array}{l}\text { C-section } \\
\text { done }\end{array}$} & $1^{\text {st }}$ stage & 29 & $46.77 \%$ \\
\hline & $2^{\text {nd }}$ stage & 33 & $53.23 \%$ \\
\hline \multirow{4}{*}{$\begin{array}{l}\text { C-section } \\
\text { done }\end{array}$} & $\begin{array}{l}\text { Intact } \\
\text { membranes }\end{array}$ & 22 & $35.48 \%$ \\
\hline & $\begin{array}{l}\text { Absent } \\
\text { membranes }\end{array}$ & 40 & $64.50 \%$ \\
\hline & Elective & 13 & $20.97 \%$ \\
\hline & Emergency & 49 & $79.03 \%$ \\
\hline \multirow{2}{*}{$\begin{array}{l}\text { Blood- } \\
\text { transfusion }\end{array}$} & Yes & 25 & $40.32 \%$ \\
\hline & No & 37 & $59.68 \%$ \\
\hline
\end{tabular}

Table 3: Variable organisms grown report of patients with SSI.

\begin{tabular}{|lll|}
\hline $\begin{array}{l}\text { Variable } \\
\text { Organism grown }\end{array}$ & $\%$ \\
\hline Acineobactor & 6 & $9.68 \%$ \\
\hline Candida & 1 & $1.61 \%$ \\
\hline Citrobactor & 1 & $1.61 \%$ \\
\hline Cons & 21 & $33.87 \%$ \\
\hline E.coli & 8 & $12.90 \%$ \\
\hline Edwartella & 1 & $1.61 \%$ \\
\hline Enterrococcus & 4 & $6.45 \%$ \\
\hline Klebsiella & 3 & $4.83 \%$ \\
\hline Meth sen staph & 1 & $1.61 \%$ \\
\hline Pseudomonas & 1 & $1.61 \%$ \\
\hline Staph aureus & 15 & $24.19 \%$ \\
\hline
\end{tabular}

\section{DISCUSSION}

In present study, incidence of post C-section wound infection was $0.34 \%$. SSI among patients $>30$ years of age $[n=22(41.93 \%)]$ and more among lower socioeconomic status $[\mathrm{n}=27(43.55 \%)]$ signifies SSI is more among patients as maternal age advances, poor nutritional status shown in Table 1. This observation is further supported by studies by Johnson et al and trans et al in their studies. ${ }^{4}$ In current study un-booked patients were $[\mathrm{n}=39(62.90 \%)]$ and total referred patients were $[\mathrm{n}=42$ $(67.74 \%)]$ who developed post C-section SSI which is similar to studies by Oslen et al $(83 \%)$ and Ansar et al $(5.8 \%)$, perhaps being a tertiary care centre where patients are referred after septic manipulations and multiple per vaginal examinations in periphery. In patients, who developed post C-section SSI, parity of the patient had no significant difference, either primigravida or multigravida developing SSI. C-section following previous abdominal surgery developing SSI in current study was $[n=32(51.61 \%)]$ which is similar by other authors like Takoudes et al with $(\mathrm{OR}=1.3)$. This observation denotes that patients undergoing $\mathrm{C}$-section after a previous abdominal surgery are more prone in developing post C- section SSI. ${ }^{5}$

Table 4: Drug sensitivity report of patients with SSI.

\begin{tabular}{|lll|}
\hline Drug sensitivity & Frequency (n) & $\%$ \\
\hline Azithromycin & 3 & $4.84 \%$ \\
\hline Cefexime & 1 & $1.61 \%$ \\
\hline Cefodroxil & 2 & $3.22 \%$ \\
\hline Fluconazole & 1 & $1.61 \%$ \\
\hline Gentamycin & 16 & $25.81 \%$ \\
\hline Imipenam & 4 & $6.45 \%$ \\
\hline Levofloxacin & 1 & $1.61 \%$ \\
\hline Linezolid & 5 & $8.06 \%$ \\
\hline Meropenam & 8 & $12.90 \%$ \\
\hline Netilmycin & 13 & $20.97 \%$ \\
\hline Pipercillin & 3 & $4.84 \%$ \\
\hline Ticarcillin & 1 & $1.61 \%$ \\
\hline Tobramycin & 4 & $6.45 \%$ \\
\hline
\end{tabular}

Table 5: Drug resistance report of patients with SSI.

\begin{tabular}{|lll|}
\hline Drug resistance & Frequency (n) & $\%$ \\
\hline Amoxicillin & 22 & $35.48 \%$ \\
\hline Cefepime & 5 & $8.06 \%$ \\
\hline Cefodroxil & 6 & $9.68 \%$ \\
\hline Cefotaxime & 2 & $3.22 \%$ \\
\hline Clauvulinic & 1 & $1.61 \%$ \\
\hline Clindamycin & 1 & $1.61 \%$ \\
\hline Erythromycin & 2 & $3.23 \%$ \\
\hline Gentamycin & 2 & $3.23 \%$ \\
\hline Imipenem & 2 & $3.23 \%$ \\
\hline Levofloxaxin & 7 & $11.29 \%$ \\
\hline Ofloxacin & 2 & $3.23 \%$ \\
\hline Pipercillin & 10 & $16.13 \%$ \\
\hline
\end{tabular}

On the other side, previous medical history complicating SSI is negligible in this study, with SSI being more common among patients without significant previous medical history, similar results found in study by Gelaw et al also. This may be due to timely correction of medical disorders like upper respiratory tract infections 
leading to cough, control of diabetes and pregnancy induced hypertension in this study center. ${ }^{6}$

SSI developed in patients without pre-operative antibiotic prophylaxis was found to be $69.35 \%(n=43)$ and preoperative surgical site preparation (hair removal) by razor blade done in $[n=41(66.13 \%)]$ developed SSI (Table 2), cochrane database meta-analysis by Tanner et al also stated increased risk of SSI [RR (2.09)] who used razor blades for pre-operative hair removal from surgical site.

SSI was most common among, emergency LSCS [n $=49$ (79.03\%)] which is comparable to Gelawat et al $[\mathrm{n}=326$ $(84.9 \%)]$. Generally, patients undergoing emergency Csection are at high risk of infections because of inadequate preparation time owing to maternal or foetal threat. Similar results are found by Killian et al also. ${ }^{7}$ Patients who had membrane rupture before LSCS developed SSI were $[\mathrm{n}=40(64.52)]$ and similar to study by Gelwa et al $[n=157(51 \%)]$ which strongly signifies the protective role of amniotic membrane.

Current study signifies, SSI occurring in those LSCS, done during second stage of labor $[\mathrm{n}=33$ (52.23\%)] which is akin to study by Jido et al, proving that longer the duration of surgery increased chances of repeated examinations and so iatrogenic risk increases. ${ }^{8}$

SSI is more common in C-section when the type of incision being Pfannenstiel incision [transverse $(88.71 \%)$ $\mathrm{n}=55$ ] identical result shown by Gelaw et al $[n=281(73.2 \%)]$ and the duration of surgery $>45$ minutes $[\mathrm{n}=35(56.45 \%)]$, which strongly emphasizes as long as the surgery lengthens SSI risk also increases.

The skin closure done using subcutaneous suture technique used in $[n=47(75.81 \%)]$ compared with mattress intermittent suture technique, subcutaneous suture provides a cosmetically good scar but possibility of hematoma or seroma formation and thus impending wound healing and proving a medium for bacterial proliferation is high is subcutaneous suture than mattress suturing technique. Secondary healing was achieved $[67.74 \%(n=42)]$ and resuturing was required only in $[\mathrm{n}=20(32.26)]$. In the study CoNS (coagulase negative staphylococcus aureus) [ $n=21(33.82 \%]$ was the most common organism isolated from post-operative incision site with clinical signs and symptoms of wound infection within 5 days of post-operative period (Table 3). CoNS are heterogeneous group of organisms classified historically as being less or non-pathogenic. ${ }^{9}$ Due to patient and procedure related changes, CoNS now present as one of the major nosocomial pathogens along with $\mathrm{S}$. epidermidis and $\mathrm{S}$. haemolyticus being the most significant species.

In present study, among drug sensitivity from wound infection (Table 4), the sensitivity for gentamicin is $[n=16(25.81)]$ followed by Netilmycin $n=13$ (20.97) in this study centre. Similarly, amoxicillin resistance was found $[\mathrm{n}=22(35.48 \%)]$ followed by pipercillin $[\mathrm{n}=10$ (16.3\%)]. The epidemiological pattern of microorganisms in the study hospital helps to use appropriate antibiotics and hence prevention of antibiotic resistance which is an emerging disaster. ${ }^{10}$

\section{CONCLUSION}

Caesarean delivery is one of the most frequent surgical interventions performed worldwide and accounts for up to $60 \%$ of deliveries in a number of countries. ${ }^{10}$ Surgical site infection occurring after delivery may lead to substantial physical and emotional burden on the mother and to a significant financial burden to the health care system. Post C-section surgical site infections represent complex clinical situations and are caused by many factors such as nature of patient and perioperative managements.

Strategies for prevention of this morbidity in patient undergoing $\mathrm{C}$-section target should be to reduce prolonged labor in absent membranes, training of surgeons to improve their skills, reduce intra operative blood loss and long operating time. To reduce surgical site infections the hospital infection control system as well as surgical site infection surveillance program has to be established. In addition, sterile environment and aseptic surgeries, use of WHO surgical safety checklist appears to be an important intervention to reduce surgical site infections. Underuse of antimicrobial prophylaxis may be a contributing factor, however, bacterial resistance mechanisms may exist and contribute to evade the effect of prophylactically administered antibiotics and contribute to the pathogenesis of wound infection. It becomes imperative therefore, to understand the local antibiotic susceptibility patterns existing in a community to design a suitable antibiotic policy. Since the risk factors and determinants of SSI are largely modifiable or preventable, it is the collective effort of the operating team and not just the operating surgeon who can prevent its occurrence.

It may be individualized to an institution but at the same time be reasonable enough not to contribute to further antibiotic resistance in the community and especially to the new-born to which the antibiotic may prevent and manage any further risk factors, with stringent infection rates in patients undergoing caesarean section deliveries.

\section{ACKNOWLEDGMENTS}

Authors would like to thank department of obstetrics and gynaecology, Umaid Hospital, Dr. S. N. Medical College, Jodhpur, Rajasthan for providing necessary assistance and support.

\author{
Funding: No funding sources \\ Conflict of interest: None declared \\ Ethical approval: The study was approved by the \\ Institutional Ethics Committee
}




\section{REFERENCES}

1. Charoenboon C, Srisupundit K, Tongsong T. Rise in cesarean section rate over a 20 -year period in a public sector hospital in northern Thailand. Arch Gynecol Obstet. 2013;287(1):47-52.

2. Miller ES, Hahn K, Grobman WA. Society for maternal-fetal medicine health policy committee. consequences of a primary elective cesarean delivery across the reproductive life. Obstet Gynecol. 2013;121(4):789-97.

3. Molina G, Weiser TG, Lipsitz SR, Esquivel MM, Uribe-Leitz T, Azad T, et al. Relationship between cesarean delivery rate and maternal and neonatal mortality. JAMA. 2015;314(21):2263-70.

4. Goepfert AR, Guinn DA, Andrews WW, Hauth JC. Necrotizing fasciitis after cesarean delivery. Obstet Gynecol. 1997;89(3):409-12.

5. Mandell, Douglas and Benett's. Principles and Practice of Infectious Diseases. 7th Ed. Surgical Site Infections and Antimicrobial Prophylaxis. Philadelphia: Churchill Livingstone, Elsevier; 2010:3891-3904.

6. Smail F, Fhofmeyr GJ. Antibiotic prophylaxis for c section. Cochrane Database Syst Rev. 2002;3:CD000933.
7. Walsh CA, Walsh SR. Extra abdominal vs intraabdominal uterine repair at cesarean delivery: a metaanalysis. Am J Obstet Gynecol. 2009;200(6):625.e1-e8.

8. Walter CJ, Dumville JC, Sharp CA, Page T. Systematic review and meta- analysis of wound dressings in the prevention of surgical-site infections in surgical wounds healing by primary intention. $\mathrm{Br} \mathrm{J}$ Surg. 2012;99(9):1185-94.

9. Larsen JW, Hager WD, Livengood CH, Hoyme U. Guidelines for the diagnosis, treatment and prevention of postoperative infections. Infect Dis Obstet Gynecol. 2003;11(1):65-70.

10. Xodo S, Saccone G, Cromi A, Ozcan P, Spagnolo E, Berghella V. Cephalad-caudad versus transverse blunt expansion of the low trans-verse uterine incision during cesarean delivery. Eur J Obstet Gynecol Reprod Biol. 2016;202:75-80.

Cite this article as: Sahay N, Jhakhar R. Study of post cesarean section wound infection and microbiological epidemiology in tertiary care centre, Western Rajasthan, India. Int J Reprod Contracept Obstet Gynecol 2020;9:2042-6. 